\title{
Performance of Groundnut (Arachis hypogaea L.) Based Millets Intercropping System in Central Dry Zone of Karnataka
}

\author{
K.V. Shwethanjali ${ }^{1}$, A.H. Kumar Naik ${ }^{2^{*}}$, T. Basavaraj Naik ${ }^{3}$ and M. Dinesh Kumar ${ }^{3}$ \\ ${ }^{1}$ Department of Agronomy, College of Agriculture, Shivamogga, Karnataka, India \\ ${ }^{2}$ All India Coordinated Research Project on Groundnut, Hiriyur, Karnataka, India \\ ${ }^{3}$ University of Agricultural and Horticultural Sciences, Shivamogga, Karnataka, India \\ *Corresponding author
}

\section{A B S T R A C T}

\section{Key w ords \\ Groundnut, Millets Equivalent yield, Land equivalent ratio \\ Article Info \\ Accepted: \\ 20 August 2018 \\ Available Online: \\ 10 September 2018}

A field experiment was conducted during Kharif 2017 at Zonal Agricultural and Horticultural Research Station, Babbur farm, Hiriyur. Pure crop of groundnut is tested against intercropping of finger millet, little millet and foxtail millet at 5:2 and 6:1 row proportions. Intercropping of groundnut (G-2-52) + foxtail millet (HMT100-1) with 6:1 row proportion showed significantly higher groundnut pod yield $\left(1,744 \mathrm{~kg} \mathrm{ha}^{-1}\right)$ and groundnut equivalent yield $\left(1,876 \mathrm{~kg} \mathrm{ha}^{-1}\right)$. On the other hand groundnut + foxtail millet with 5:2 row proportion recorded significantly higher land equivalent ratio(1.16) and the highest mean of monetary advantage index $\left(10,536 \mathrm{Rs}^{-1} \mathrm{ha}^{-1}\right)$.

\section{Introduction}

In recent years, a trend in agricultural production system has changed towards achieving high productivity and promoting sustainability over time. Farmers are developing different crop production systems to increase productivity and sustainability since ancient times. This includes crop rotation, relay cropping and intercropping of major crops with other crops. However, several factors like cultivar, seeding ratios, planting pattern and competition between mixture components affect the growth of species in intercropping (Caballero et al., 1995, Carr et al., 2004). The major objectives of intercropping are to produce an additional crop, to optimize the use of natural resources and to stabilize the yield of crops and to overcome the risk. The intercropping systems involve smart risk protection combinations. Groundnut in particular provides more stability and ensures better monetary returns. However, to provide stability in the returns, it is always advisable that cereal or short duration compatible pulse crop is introduced as a component crop with groundnut to ensure dietary requirement in terms of quality. Groundnut crop can accommodate rapidly growing short duration crops like millets and would prove to be a viable intercropping system. Groundnut, one of the important 
oilseed crop of tropical and sub-tropical regions of the world belongs to the family Leguminoceae and it is known as the 'king of oilseed' crops. Groundnut is also called poor man's almond. Itis the world's fourth most important source of edible oil and third most important source of vegetable protein It contains about 40-45 per cent oil, 25-30 per cent protein, 25 per cent carbohydrate in addition to the minerals and vitamins (Desai $e t$ al., 1999). Millets are hardy and resilient crops grown in diverse agro-climatic adverse condition, which have been contributing to the food security with important role in the livestock dependent communities for their livelihood. In recent years, there has been an increasing recognition of the importance of millets in India. The information available on the suitability of intercropping systems in groundnut with millets is meager in Central Dry Zone of Karnataka. Hence a present investigation was taken up to evaluate the productivity of groundnut with small millets at different row ratio on vertisols under rainfed condition.

\section{Materials and Methods}

The field experiment was conducted at Zonal Agricultural and Horticultural Research station, Babbur farm, Hiriyur during kharif 2017 under rainfed condition. The station is situated at $13^{\circ} 57^{\prime} 32^{\prime \prime}$ North latitude and $70^{\circ}$ 37' 38" East longitude and an altitude of 606 meters above mean sea level (MSL). The soil of the experimental site is vertisol with slightly alkaline $\mathrm{pH}$ (8.10), organic carbon (1.90 $\left.\mathrm{g} \mathrm{kg}^{-1}\right)$, available nitrogen $\left(258 \mathrm{~kg} \mathrm{ha}^{-1}\right)$, available phosphorus (35 kg ha $\left.{ }^{-1}\right)$ and available potassium (315 $\left.\mathrm{kg} \mathrm{ha} \mathrm{ha}^{-1}\right)$. Intercropping of millets like finger millet (ML-365), little millet (Sukshema) and foxtail millet (HMT 100-1) with groundnut (G-2-52) in 5:2 and 6:1 row proportion on vertisols was studied under rainfed condition. The treatments included in the experiment were
$\mathrm{T}_{1}$ : Sole groundnut, $\mathrm{T}_{2}$ : Sole finger millet, $\mathrm{T}_{3}$ : Sole little millet, $\mathrm{T}_{4}$ : Sole foxtail millet, $\mathrm{T}_{5}$ : Groundnut + finger millet $(5: 2), \mathrm{T}_{6}$ : Groundnut + little millet (5:2), $\mathrm{T}_{7}$ : Groundnut + foxtail millet $(5: 2), \mathrm{T}_{8}$ : Groundnut + finger millet (6:1), $\mathrm{T}_{9}$ : Groundnut + little millet (6:1) and $\mathrm{T}_{10}$ : Groundnut + foxtail millet $(6: 1)$. The experiment was laid out in a randomized complete block design with three replications. The data on growth and yield attributes were recorded. Statistical analysis was done as per the methodology suggested by Gomez and Gomez (1984).

\section{Results and Discussion}

Groundnut pod yield obtained in sole and intercropping treatments varied significantly. Among various treatments significantly higher groundnut pod yield $\left(1,862 \mathrm{~kg} \mathrm{ha}^{-1}\right)$ was recorded in sole groundnut. This could be due to higher plant population and competition free environment as compared to intercropped groundnut which resulted better growth and yield parameters. Similar results were reported by Shalim et al., (2003). Among the intercropping treatments, groundnut + foxtail millet (6:1) recorded significantly higher groundnut pod yield and groundnut equivalent yield $\left(1,744 \mathrm{~kg} \mathrm{ha}^{-1}, 1,876 \mathrm{~kg} \mathrm{ha}^{-1}\right)$ which was on par with the groundnut + little millet $(1,683$ $\mathrm{kg} \mathrm{ha}^{-1}, 1,822 \mathrm{~kg} \mathrm{ha}^{-1}$ ) and groundnut + finger millet $\left(1,590 \mathrm{~kg} \mathrm{ha}^{-1}, 1,809 \mathrm{~kg} \mathrm{ha}^{-1}\right)$ under same row ratio. This might be due to higher yield of groundnut in the intercropping system and thereby envisages effective utilization of the resources along with millets. Similar findings have been reported by Shivakumar and Yadahalli (1996). All intercropping treatments recorded the higher land equivalent ratio than the sole crop (Willey and Mead 1980). The obvious reason for yield advantage in the intercropping system was due to the fact that the component crops differed in utilisation of growth resources and converting them more efficiently resulting in a higher yield per unit 
area than that produced by the sole crops (Patil et al., 2010). Among the various treatments, groundnut + foxtail millet $(5: 2)$ recorded significantly higher land equivalent ratio (1.16) which was on par with the groundnut + foxtail millet and groundnut + finger millet with 6:1 row ratio $(1.14$ and 1.13 respectively). These results are in conformity with Ahmad and Prasad (1996) findings. Highest of monetary advantage index was recorded in groundnut + foxtail millet $(10,536$ Rs. ha $\left.^{-1}\right)$ followed by groundnut + foxtail millet (10,254 Rs. ha $\left.{ }^{-1}\right)$ under 5:2 and 6:1 row ratio respectively. These results are in confirmation with the findings of Padhi et al., (2010) (Table 1).

Table.1 Pod yield, groundnut equivalent yield and yield advantage as influenced by the intercropping of groundnut and millets at different row proportions

\begin{tabular}{|c|c|c|c|c|c|}
\hline Treatments & $\begin{array}{c}\text { Groundnut } \\
\text { Pod Yield } \\
\left(\mathrm{kg} \mathrm{ha}^{-1}\right)\end{array}$ & $\begin{array}{c}\text { Millet } \\
\text { Grain } \\
\text { Yield } \\
\left(\mathrm{kg} \mathrm{ha}^{-1}\right)\end{array}$ & $\begin{array}{c}\text { Groundnut } \\
\text { equivalent } \\
\text { yield } \\
\left(\mathrm{kg} \mathrm{ha}^{-1}\right)\end{array}$ & $\begin{array}{c}\text { Land } \\
\text { equivalen } \\
\text { t ratio }\end{array}$ & $\begin{array}{c}\text { Monetary } \\
\text { advantage } \\
\text { index } \\
\left(\text { Rs. ha } \mathbf{h}^{-1}\right)\end{array}$ \\
\hline T1: Sole groundnut & 1862 & - & 1862 & 1.00 & - \\
\hline T2: Sole finger millet & - & 2235 & 1152 & 1.00 & - \\
\hline T3: Sole little millet & - & 1252 & 619 & 1.00 & - \\
\hline T4:Sole foxtail millet & - & 1584 & 641 & 1.00 & - \\
\hline T5: Groundnut + finger millet $(5: 2)$ & 1290 & 761 & 1683 & 1.03 & 2182 \\
\hline T6: Groundnut + little millet(5:2) & 1334 & 477 & 1569 & 1.10 & 6351 \\
\hline T7: Groundnut + foxtail millet $(5: 2)$ & 1486 & 570 & 1717 & 1.16 & 10536 \\
\hline T8: Groundnut + finger millet (6:1) & 1590 & 424 & 1809 & 1.05 & 3096 \\
\hline T9: Groundnut + little millet (6:1) & 1683 & 282 & 1822 & 1.13 & 9330 \\
\hline T10: Groundnut + foxtail millet (6:1) & 1744 & 327 & 1876 & 1.14 & 10254 \\
\hline S.Em \pm & 94.62 & 62.10 & 89.18 & 0.05 & - \\
\hline CD at $5 \%$ & 285.8 & 186.19 & 264.97 & 0.15 & - \\
\hline
\end{tabular}


The present study clearly indicate that highest pod yield and groundnut equivalent yield was recorded in groundnut + foxtail millet $(6: 1)$. However, land equivalent ratio and monetary advantage index was found to be higher in groundnut + foxtail millet $(5: 2)$.

\section{References}

Ahmad, S. and Prasad, N. K., 1996, Sustainable association of littlemillet with groundnut and pigeonpea. Indian J. Agron., 41 (3): 354-358.

Caballero, R., Goicoechea, E. L. and Hernaiz, P. J., 1995. Forage yield and quality of common vetch and oat sown at varying seed ratios and seeding rates of common vetch. Field Crops Res., 41: 135-140.

Carr, P.M., Horsley R.D. and Poland, W. W., 2004. Barley, oat and cereal-pea mixtures as dryland forages in the Northern Great Plains. Agron. J., 96: 677-684.

Desai, B. B., Kotecha, P. M. and Salunkhe, D. K., 1999, Science and technology of groundnut, biology, production, processing and utilization. Naya Prakash Publication, New Delhi, India. pp. 185-199.

Gomez, K. A., and Gomez, A. A., 1984, Statistical procedures for Agricultural research. John-Wiley and sons, Inc, New York, pp-680.

Padhi, A. K., Panigrahi, R. K. and Jena, B. K., 2010, Effect of planting geometry and duration of intercrops on performance of pigeonpea-finger millet introcropping systems. Indian J. Agric. Res., 44 (1): $43-47$.

Patil, N.B., Halikatti, S.I., Sujay, Y.H., Prasanna Kumar, B.H., Sanjay, C., Topagi and Pushpa, V., 2010, Influence of intercropping on the growth and yield of little millet and pigeonpea. International Journal of Agricultural Sciences, 6(2): 602-604.

Shalim, U. M., Rahaman, M. J, Shamim, A. B., Uddin, M. J. and Rahaman, M. M., 2003, Performance of Performance of intercropping of maize with groundnut in saline area under rainfed condition. Pakistan Journal of Biological Sciences, 6 (2): 92-94.

Shivakumar, B. G. and Yadahalli, Y. H., 1995, Economics of intercropping in finger millet under late sown dryland conditions. Farming Syst, 11 (1-2): 1-7.

Willey, R.W. and Mead, R., 1980, A competitive ratio for quantifying competition between intercrops. Exp. Agric., 16: 117-125.

\section{How to cite this article:}

Shwethanjali, K.V., A.H. Kumar Naik, T. Basavaraj Naik and Dinesh Kumar, M. 2018. Performance of Groundnut (Arachis hypogaea L.) Based Millets Intercropping System in Central Dry Zone of Karnataka. Int.J.Curr.Microbiol.App.Sci. 7(09): 2917-2920. doi: https://doi.org/10.20546/ijcmas.2018.709.362 